\title{
A Study of Socio Economic, Self Confidence and Problems Faced By Working Women
}

\author{
Ms. Lalita kumari \\ Faculty of Sociology/Singhania University.Pacheri Bari,Ditt.Jhunjhunu, Rajasthan. India
}

\begin{abstract}
Self confidence and problems faced by working women.150 Women entrepreneur were selected from rural and urban areas of Dist. Ludhiana, of Punjab ,India, using convenience sampling techniques Questionnaire, check list and ranking methods were used for data collection. Results- The mean age group of the subject ranges from 21 to 40 years. $t$ value of self confidence in urban and rural working women was 0.73 that is non significant at both levels. Socio economic status was significantly higher in urban women than rural. There was no significant relationship between socio economic status and self confidence of working women of Ludhiana Distt.. Study finding has shown that 75\% of working women face problem of role conflict,68.75\% problem of lack of persistence, $62 \%$ face administrative problems.
\end{abstract}

Keywords- Innovativeness, Self confidence, social attitude, Women empowerment, Women entrepreneur

\section{Introduction}

Women have been regarded as the nuclei of nation and builder and molder of its destiny. It is fact that when there is development of women, family develops, the society develops and the country develops'. They are the catalyst of development. Time went out when Indian women are confined to four walls of their homes with their immense strength and potential. Now they are the important part of economic development. They also generate employment opportunities and contribute in improving family's living standard.

Today's women must supplement the family income using their potential and skills that they possess. Their skills and competencies may be sharpened and turned by way of training. Thus, women in India, no longer need to wait for employment outside home. They can successfully start their enterprise and earn their livelihood.

Women have played a very small role in the field of business. In a male dominated society, women have been victims of social prejudices and discrimination. Women are considered to be weak, passive and dependent on others. They are not exposed to risks which adversity affect their self confidence, innovativeness and risk taking ability. In several developing countries like India, marriage is the only career for most women. Women have confined their activities to selected professions such as teaching, nursing, medicine and office work. Very few women enter professions like industry, engineering, trade etc. But in the recent years the scenario has changed. Now due to many reasons like education, women empowerment etc. women entrepreneurship has been recognized all over the world as an essential ingredient of economic development. Although there are a lot of problems in the way of women entrepreneurship yet with the support of family and government the prospects of women entrepreneurship can become bright

The primary objective of the present study was to check the hindrances and the motivational factors responsible for the women entrepreneurship in general. But other objectives may be stated as below:

\section{Objectives of The Study}

The present study was related to prospects, problems and potential of working women. The objectives of the study are:

1. To identify the problems unique to women in setting up and running their enterprise.

2. To identify problems regarding existing policies, programmes, institutional network and the involvement of support agencies in promoting women entrepreneurship.

3. To find out the possibility of support from family members in setting up their venture.

4. To find out the impact of tough competition, tradition and custom, extent of market knowledge for setting up business.

5. To study the relationship between socio-economic status and self confidence of the adolescents.

Scholar of Singhania University 


\section{Research Design}

\section{Methods}

The conceptual structure with in which this research is conducted is descriptive is nature and it brings forward the results concerning the set objectives, through the fact finding enquiries. Moreover it describes the state of affairs, as it exists at present.

\section{Data Collection Method}

For the purpose of this research both primary and secondary data have been used. But basically primary data has been used. Primary data is the data that is collected for the first time. It was collected through questionnaire (consisting of open ended and check list questions, ranking method was also used for giving priority to problems), observation and interviews. Secondary data is the data which is already published and is available through different media. It was collected through reports, books, websites, magazines, journals

\section{Sampling Techniques}

Sampling technique availed is non probability convenience sampling as it was a sample survey in accordance with the convenience of researchers. Selected samples from different areas of Ludhiana district were selected for the study purpose. The major findings of the study are as follows:

Majority of women entrepreneurs were in the age group of 21-40 years and the women related to different occupational category had different age to enter in their occupation. Most of the women

entrepreneurs are married and have their monthly income between 5000-10000 and 10000-20000. 31\% of women are running their beauty parlors successfully $25 \%$ of the women running their boutiques successfully.

Most of the women belonging to different occupational categories were doing some work for spending their leisure time. But many of the women are doing some work for providing financial security to family members.

The number of women entrepreneurs is more in urban areas as compared to rural areas. It is because of more facilities available at urban areas.

$38 \%$ of the women said that minimum qualification is required for running their existing business. $37 \%$ of the women suggested that more then 1 lakh is required as initial capital for running their existing business. $38 \%$ of the women declared that proper market knowledge is required for setting up their business.

Most of the women entrepreneurs are running their business successfully since last 10 years. They are highly satisfied with their career. Most probably feeling of self dependency gives them confidence. Approximately $60 \%$ women entrepreneurs have received support from family members either from parental side or from in-laws or from friends/relatives.

It was also found that most of the women entrepreneurs are effective in the areas like interpersonal relations, ethical and moral strength, and adequacy of communication but they lack in areas like intellectual operation, behaviour, emotional stability and operations

Figures and Tables

Table 1. Mean scores of self-confidence of urban and rural working women

\begin{tabular}{|l|c|c|c|c|c|}
\hline Group & N & Mean & S.D. & S.E. & 't'-value \\
& & & & \\
\hline Urban & 75 & 28.43 & 8.66 & & \\
Rural & 75 & 27.37 & 9.01 & 1.43 & $0.73^{*}$ \\
& & & & & \\
\hline
\end{tabular}

* - Value non-significant at both levels of confidence $(0.05 \& 0.01)$ The study results shows that mean scores of self confidence of women of urban and rural area are $\mathbf{2 8 . 4 3}$ and 27.37 respectively. S.D. for urban and rural areas are 8.66 and $\mathbf{9 . 0 1}$ respectively and the " $t$-value of the difference is $\mathbf{0 . 7 3}$ which was no significant at both levels of confidence. It shows that there is no difference between rural and urban women self confidence. 


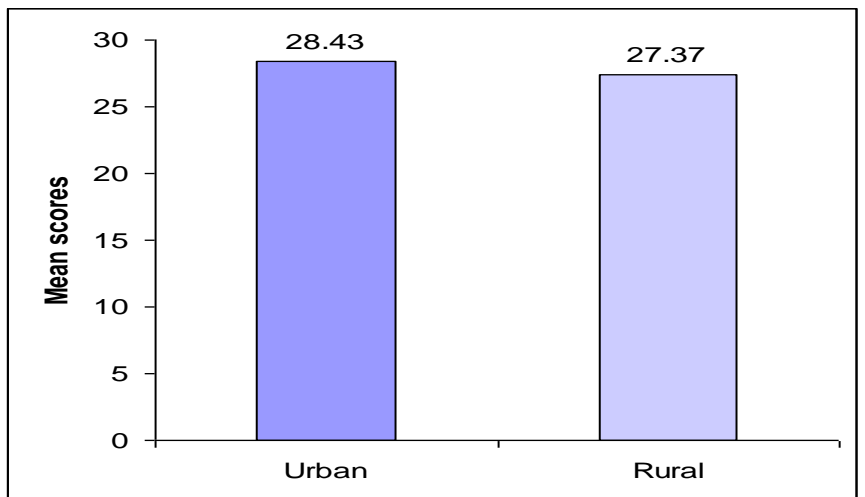

Figure 1. Mean Scores of Self-Confidence of Urban and Rural working women

Table 2. Mean scores of socio-economic status of rural and urban working women

\begin{tabular}{|l|l|l|l|l|l|}
\hline Group & N & Mean & S.D. & SE $_{\mathrm{D}}$ & t-value \\
\hline Urban & 75 & 81.84 & 16.91 & 2.35 & $3.20^{*}$ \\
Rural & 75 & 74.30 & 11.40 & & \\
& & & & & \\
& & & & & \\
\hline
\end{tabular}

*Value significant at both levels of confidence $(0.05$ and 0.01$)$ Table 2 shows the mean scores of socio economic status of urban and rural women were 81.84 and 74.30 respectively. S.D. for urban and rural areas were 16.91 and 11.40 respectively and 't' value of the difference is 3.20 which was significant at both levels of confidence. Thus there exists significant difference between rural and urban women.

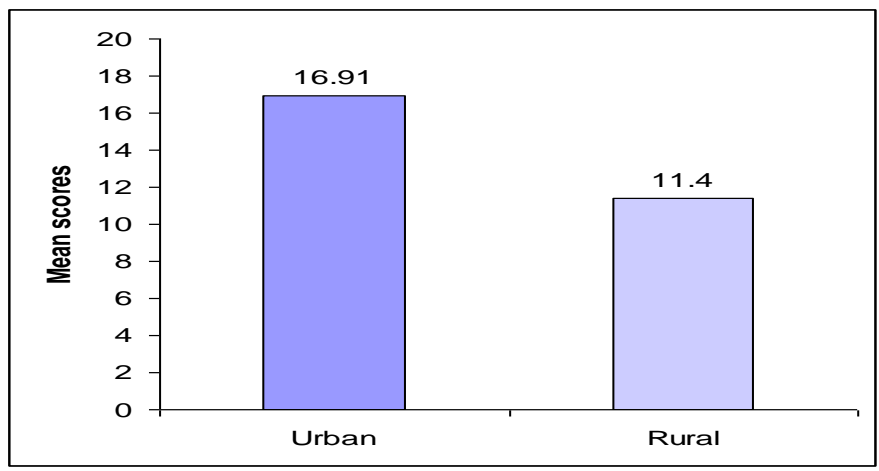

Figure2. Mean Scores of Socio-Economic Status of Urban and Rural working wome

Table 3. Co-efficient of correlation between socio economic status and self-confidence of women

\begin{tabular}{|c|c|c|c|}
\hline S.No. & Group Variables & $\mathbf{N}$ & $\mathbf{r}$ \\
\hline 1 & $\begin{array}{c}\text { Socio economic } \\
\text { Self Confidence }\end{array}$ & 150 & $0.13^{*}$ \\
\hline
\end{tabular}

* Non-significant at 0.05 and 0.01 level. Table 3 represents the coefficient of correlation between socio economic status and self-confidence of women. It comes out 0.13 which was no significant at both levels of confidence. This indicates that there exists no significant relationship between socio- economic status and self - confidence of women of Ludhiana district. 
A Study Of Socio Economic, Self Confidence And Problems Faced By Working Women

Study findings has shown that $\mathbf{6 5 \%}$ women face problem in legal formalities and $\mathbf{5 8 . 7 5 \%}$ face problem of lack of market knowledge followed by $\mathbf{5 8 . 7 5 \%}$ considered lack of family support as major problem, $\mathbf{5 8 . 7 5 \%}$ face problem of tough competition and $\mathbf{6 0 \%}$ customs and tradition, $\mathbf{4 6 . 2 5 \%}$ involvement of high risk as problem, $\mathbf{4 6 . 2 5 \%}$ market problem as major problem, $\mathbf{4 1 . 2 5 \%}$ perceives lack of initial capital as major problem, $\mathbf{3 6 . 2 5 \%}$ perceives family stress and $\mathbf{3 4 \%}$ government policy as major problem, $\mathbf{6 2 . 5 \%}$ supports that previous training help in the growth of business, $\mathbf{6 2 . 5 \%}$ face administrative problem in running a business, $\mathbf{7 5 \%}$ face problem of role conflict i.e. professional vs. personal, $\mathbf{3 7 . 5 \%}$ have problem of physical stay that is cannot stay at night,62.5\% have psychological problem of low level of motivation,68.75\% problem of lack of persistence, $\mathbf{6 2 . 5 \%}$ feels low energy level while starting the venture, $\mathbf{8 1 . 2 5 \%}$ support place of residence helps in growth of business.

In the present study it has been found that due to modernization, globalization and spread of education women are now seeking gainful participation in several fields. No doubt, women are also facing many problems like shortage of finance, shortage of raw material, stiff competition, high cost of production, low mobility, family responsibility, social attitudes etc. But women also have the potential and will to establish and manage enterprise of their own. So there is a need of encouragement and support. With assistance and support of family members and government women can join the main stream of national economy and contribute to the country's economic progress.

\section{Recommendations}

1. Create a social awareness to treat women entrepreneurs on par with their male counterparts.

2. Government should try to make entrepreneurship more acceptable in society through education and awareness campaigns.

3. The government should remove all the barriers in the registration of units, in obtaining credits, in taxation, shortage of power etc.

4. Achievement, motivation, training in the particular industry should be provided.

5. Suitable assistance in the choice of appropriate machinery and equipment should be provided.

\section{Refernces}

[1]. Baumgarte1, H., Dunn, L.E., Sullivan, G.I.(1977). "Management Education, Company Climate and Innovation", Journal of General Management: 4(2), p.1

[2]. Banks, M.C. and Burs, A.L. (1987). "Managerial Training What Companies Want and How They Get it?", SAM Advanced Management Journal: 52 (1), p.26.

[3]. Campbell, J.P. et a1 (1970) Managerial Behavior, Performance and Effectiveness. U.S.A.: McGraw-Hill.

[4]. Meager.(2009). "The Role of Training and Skills Development in Active Labour Market Policies" “,International Journal of Training and Development, Vol. 13, Issue 1, pp. 1-18, March 2009

[5]. Marquardt. (2000). "Training And Development In The United States, International Journal of Training \& Development, Vol. 4, No. 2, PP. 232-23

[6]. Alzalabani.(2002). "Training and Development in Saudi Arabia, International Journal of Training and Development, Vol. 6, pp. 125140,2002

[7]. Lehner (2003). “: Training and Development in Austria , International Journal of Training and Development, Vol. 7, pp. 217-226, September 2003 